\title{
Raspberry Pi: a 35-dollar device for viewing DICOM images*
}

Raspberry Pi: dispositivo de 35 dólares para visualização de imagens DICOM

\section{Omir Antunes Paiva ${ }^{1}$, Renata de Oliveira Moreira ${ }^{1}$}

Paiva OA, Moreira RO. Raspberny Pi: a 35-dollar device for viewing DICOM images. Radiol Bras. 2014 Mar/Abr;47(2):99-100.

Abstract Raspberry Pi is a low-cost computer created with educational purposes. It uses Linux and, most of times, freeware applications, particularly a software for viewing DICOM images. With an external monitor, the supported resolution $(1920 \times 1200$ pixels $)$ allows for the set up of simple viewing workstations at a reduced cost.

Keywords: Raspberry Pi; DICOM; Images; Viewing; Low cost.

Resu mo Raspberry Pi é um computador de baixo custo criado com propostas educativas. Utiliza o Linux e seus softwares são gratuitos, em sua maioria. Há softwares para visualização de imagens no formato DICOM. Com o uso de um monitor externo, a resolução suportada (1920 $\times 1200$ pixels) permite a criação de estações de visualização simples de exames com custo reduzido.

Unitermos: Raspberry Pi; DICOM; Imagens; Visualização; Baixo custo.

Raspberry Pi (Figure 1) is a computer developed by Raspberry Pi Foundation, a British charity organization ${ }^{(1)}$, with the purpose of stimulating the study of computer science $^{(2)}$. The computer components were selected in a way to optimize the cost of the device. It is a quite simple instrument, but capable of accomplishing several specific tasks.

The growth of costs in radiology ${ }^{(3)}$ has led to an increasing effort to optimize expenses ${ }^{(3-5)}$. Sometimes, technology can help to reduce such expenses ${ }^{(5)}$. Two Raspberry Pi features are remarkable in such an aspect: its weight of 45 grams and, mainly, its price, corresponding to USD $35.00^{(6)}$.

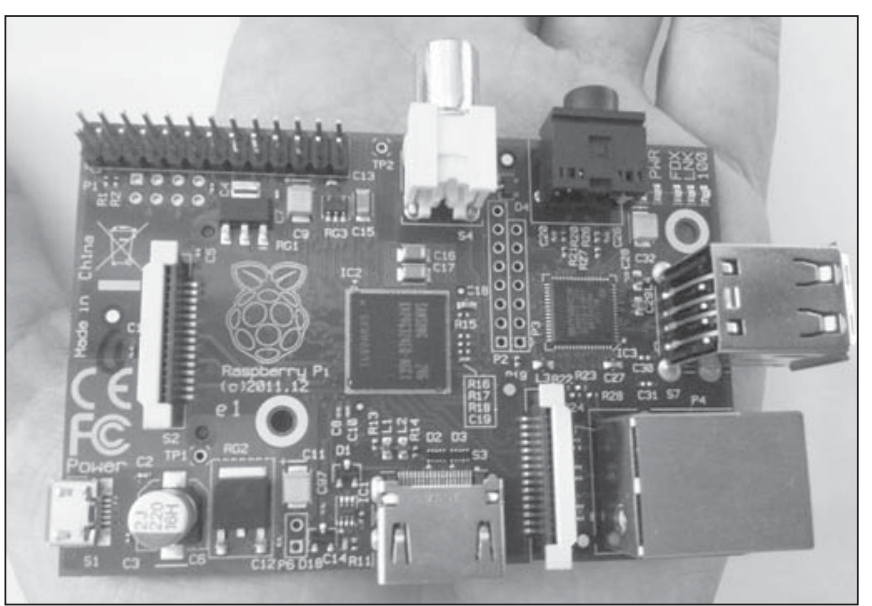

Figure 1. Raspberry Pi (personal file).

* Study developed at Hospital das Clínicas - Universidade Federal de Minas Gerais (UFMG), Belo Horizonte, MG, Brazil.

1. MDs, Residents of Radiology and Imaging Diagnosis at Hospital das Clínicas Universidade Federal de Minas Gerais (UFMG), Belo Horizonte, MG, Brazil.

Mailing Address: Dr. Omir Antunes Paiva. Unidade Funcional de Apoio Diagnóstico e Terapêutica por Imagem. Avenida Proferssor Alfredo Balena, 110, Centro. Belo Horizonte, MG, Brazil, 30130-100. E-mail: oantunesp@gmail.com.

Received May 1st, 2013. Accepted after revision September 25, 2013.
There is no hard disk in the Raspberry $\mathrm{Pi}$, and the operational system as well as all the files are stored in a SD card. The device has a high definition video output supporting display monitors up to 2.2 megapixels (HDMI, $1920 \times$ 1200 pixels) and a second RCA video output. There are eight programmable GPIO (general purpose input/output) pins which may, for example, be connected with sensors, engines or relays (electrically operated switches) to control other devices.

Contrary to the increasing use of expensive computers which end up being underutilized, Raspberry Pi does not include any peripheral device; and, in such a case, it is necessary to separately acquire a common power source with a micro-USB output and other items as necessary (keyboard, mouse, monitor and other adaptors).

The supported operational systems utilize Linux platform and most of them are freeware and open source. There is an immense freedom for customization of the device and of its functions by means of the Python programming language.

There are some applications for viewing DICOM files, such as Aeskulap ${ }^{(7)}$. Most of them are simple softwares from which one should not expect advanced resources, but they play their role perfectly as DICOM files viewers, whether such files come from radiography, mammography, ultrasonography, computed tomography or magnetic resonance imaging.

With an external display monitor utilizing the maximum resolution supported by the Raspberry $\mathrm{Pi}$, it is possible to assemble a simple image viewer workstation that is at least reasonable for the tasks of a non-radiologist physician, with an incomparable cost-benefit ratio. The Raspberry Pi would be useful for the dissemination of images viewer workstations throughout large institutions, consequently contributing for a reduction of the significant images printing $\operatorname{costs}^{(8)}$. 
Because of its vast capacity for customization, Raspberry $\mathrm{Pi}$ is an instrument which deserves deep study, considering that its impact on radiology costs may be significant.

\section{REFERENCES}

1. Wikimedia Foundation. Raspberry Pi Foundation. [Internet]. [acessado em 15 de abril de 2013]. Disponível em: http://en.wikipedia.org/ wiki/Raspberry_Pi_Foundation.

2. Raspberry Pi Foundation. About us. [Internet]. [acessado em 15 de abril de 2013]. Disponível em: http://www.raspberrypi.org/about.

3. Vela JG, Bhaya A, Monteiro AMV, et al. Digitalização de filmes radiográficos com costura de imagens. Radiol Bras. 2011;44:233-7.
4. Asevedo FMF, Koch HA. Avaliação dos custos para a implantação de um serviço de mamografia. Radiol Bras. 2004;37:101-5.

5. Pellegrinetti B, Magna LA. Sobre uma metodologia de apresentação de imagem médica. Radiol Bras. 2004;37:211-3.

6. Wikimedia Foundation. Raspberry Pi. [Internet]. [acessado em 15 de abril de 2013]. Disponível em: http://en.wikipedia.org/wiki/ Raspberry_Pi.

7. Medical imageworks LLC. Program: Aeskulap - DICOM Viewer. [Internet]. [acessado em 15 de abril de 2013]. Disponível em: http:// www.idoimaging.com/program $/ 303$.

8. Brasil SAS. Custeio baseado em atividades aplicado à prestação de serviços médicos de radiologia. Rev Contab Finanç - USP. 2004; 15:63-79. 